\title{
Introduction
}

\section{Rethinking Sino-U.S. Rapprochement: Unconventional Forms of Diplomacy}

Webster's Third New International Dictionary broadly defines diplomacy as "an art and practice of conducting negotiations between nations for the attainment of mutually satisfactory terms."1 Since very few existing definitions manage to encompass all forms of diplomatic interactions, the understanding of the term continues to change as the academic scholarship on the issue evolves. Unfortunately, the academic understanding of diplomacy often lags behind the actual practices, leaving scholars forced to "catch up" with modern day developments.

Much like historians, students of political science and international relations continue to grapple with the ambiguity of the term and attempt to produce a comprehensive framework within which one can understand and study diplomacy. A majority of scholars agree that they and their colleagues should leave the traditional view on diplomacy as a nation-to-nation exchange in the past. Some even go as far as to declare the "crisis of state-led diplomacy," in which governmental institutions are under the heavy restraint of both their bureaucratic nature and the necessity to conform with century-long traditions. ${ }^{2}$

Historical science had to travel a path similar to political science in expanding its understanding of the past and the role of diplomacy in it. Arguably, it was the most important processes of the 2oth Century (two world wars, the Cold War, decolonization, the fall of the Soviet Union, and globalization,

1 Philip Babcock Gove (ed.), Webster's Third New International Dictionary (Springfield, MA: Merriam-Webster Publishers, 1993), 638.

2 For a good overview of existing literature, see Sascha Lohmann. "Understanding Diplomacy in the 21st Century," Working Paper No.11, Project "Diplomacy in the 21st Century," March 2017, Stiftung Wissenschaft und Politik (swP)/ German Institute for International and Security Affairs. 
among the most important events and trends) which created a new political reality, enriched the toolkit of a diplomat, and enhanced the ability of state and non-state actors to advance their cause on international arena.

Originally, it was the diplomatic history that defined diplomacy primarily as the interactions between states and it focused on uncovering the truth about government-to-government exchanges. Later on, historians moved on to studying diplomacy within the framework of international history, in which nations took prevalence over states, further expanding the possible interpretations of diplomatic activities. In the early 1990s, with the wider access to archival materials from the Soviet bloc, historians came to realize that the world of diplomacy formed a mosaic of state and non-state actors pursuing their goals and employing a variety of political and non-political instruments to become successful in their pursuit. And in the last decade, with the advent of transnational history as a broader area of studies, the scholarly horizons finally have opened up to include more sophisticated forms of diplomatic engagement, further complicating the possibility of providing a clear-cut definition for the term. ${ }^{3}$ Inclusion of unconventional forms of diplomacy into the wider scholarship on diplomatic interactions helps explore newly-emerging archival materials, as well as oral testimonies and written memoirs of direct participants in these engagements.

Many of these participants hardly would approve references to them as diplomats, but among the goals they pursued in their activities diplomacy often came last. Nevertheless, the definition itself has to evolve. Diplomacy as a term now incorporates public diplomacy, sports diplomacy, cultural diplomacy, trade consultations, exchanges in the areas of science and technology, and many other forms of engagement. Without those, the full scale of political, societal, and cultural changes remains outside of our reach.

This theme issue presents three articles all of which try to enrich our understanding of Sino-U.S. relations during the period of rapprochement during the 1970s. The authors move away from conventional narratives of bilateral engagement and help to shed a new light on the multifaceted exchanges between the People's Republic of China (PRC) and the United States, demonstrating how many factors actually had to come into play for the Sino-American normalization to materialize. At the same time, the articles trace friction between different political groups or factions and showcase the mechanisms through which

3 Akira Iriye has called for a wider use of the term "transnational history." See, for instance, Akira Iriye, Global and Transnational History: The Past, Present, and Future (Basingstoke: Palgrave Macmillan, 2013); Akira Iriye and Pierre-Yves Saunier (eds.), The Palgrave Dictionary of Transnational History: From the Mid-rgth Century to the Present Day (Basingstoke: Palgrave Macmillan, 2009). 
resolution of these tensions occurred. In trade, science and technology, and public diplomacy, the political factions and different government agencies or institutions pursued personal or institutional goals, often creating additional obstacles to the progress of Sino-American rapprochement. At the same time, these obstacles ultimately were not able to stymie the normalization-state interests prevailed over personal agendas-as the greater good of respective countries ultimately outweighed the vested interests of bureaucrats.

Jeffrey Crean in his article titled "A New Sphere of Influence: Table Tennis Diplomacy and the National Committee on U.S.-China Relations [NCUSCR]" focuses on examining the inner workings of a non-governmental institution which left a remarkable trace in the history of Sino-American rapprochement. In the account, he provides a good overview of the American political landscape and how the politicians and intellectuals positioned themselves in light of the new China policy that the Nixon administration formulated. Readers will observe the ebb and flow of interactions between people with various political convictions all laboring at achieving similar goal—bringing China a little closer to the American public. Despite the necessity to weather the opposition of the right-wing China Lobby to any outreach to the Chinese Communists and to keep a safe distance from the left-wing activism, the NCUSCR would manage not only to stay afloat, but engage in various activities. Nevertheless, as the Sino-U.S. relationship progressed, the committee became involved in organizing international events of much larger magnitude. And with that came a generational change in the leadership of this public diplomacy organization - the intellectuals, many of them college professors, who viewed the core of their mission as educating the American public, soon found businessmen replacing them. The latter had organizational savvy to coordinate the exchanges on an international level.

Xiayang Ding in his article titled "Diplomacy vs. Economics: Examining the Roots of Decline in Sino-U.S. Trade in 1975" explains the decline in Sino-U.S. trade in 1975 from a fresh perspective. He demonstrates the limitations of existing scholarship on the issue and proves that the impact of domestic politics, diplomatic conflicts, and trade disputes were not as dramatic as the academic literature previously has alleged. Most of these factors existed over a prolonged period of time and hardly could explain the significant decline in trade in 1975 in particular. In the article, Ding argues that it was in fact the shortage of foreign currency that accounted for the Chinese decrease in import volume from the United States. The crisis informed the subsequent economic reform in the PRC, while the top leaders still insisted on establishing full diplomatic relations with the United States as a prerequisite for unlimited trade development. The shortage of foreign currency in 1974 created pressure and its effect on U.S. 
trade practices led the Chinese mid-level economic leaders to reconsider their approach to trade- they grew more responsive to the U.S. requests about making adjustments to the goods they were exporting to China. Thus, it is safe for one to assume that the decline in trade in 1975 was a byproduct of global and domestic economic processes, and the PRC learned a lot about navigating global markets and building healthy economic relations with the Americans.

Chenxi Xiong explores the impact of ideas and views of Deng Xiaoping on Chinese scientific and technological development and engagement with the United States in his article titled "Deng Xiaoping's Views on Science and Technology: Origins of the Sino-U.S. Science and Technology Cooperation, 1977-1979." His account showcases the role of individual ideas in shaping domestic and foreign policy, and the ability of a new vision corroborated by facts to convince even the hardened conservatives of the necessity to adjust relations with an ideological foe. The article states that in the early 1970s, Deng already had demonstrated interest in Chinese science and technology development, but political turmoil prevented him from turning his ideas into reality. Once reinstated, he became directly involved in S\&T policy-making and paid an enormous amount of attention to education. As his power grew, Deng tried to rally the political elites behind his cause through overseas investigations and, ultimately, he managed to change the views of Chinese leadership. At the same time, the article argues, President Jimmy Carter's administration was observant enough to notice the shift in Chinese attitudes and act on it. Xiong thus tells a story of one individual who through his unique outlook on the role of science and technology in state-building managed to transform policies in two countries.

As the variety of diplomatic activities continue to evolve, people engaged in diplomacy both in the PRC and the United States have learned to use these to improve the quality of bilateral communication and find alternatives to open public confrontations. This is particularly important because, given the intricate economic connections between the two states, neither can sustain economic growth and development without the support of the other. Therefore, it is the greatest challenge for the Chinese and the Americans alike to find more effective ways of engagement, search for common ground, and create opportunities for compromise. Arguably, the ability of academia to stop the game of "catch up" and start offering definitive diplomatic solutions to the existing bilateral issues will define the future of bilateral relations and the applicability of the Thucydides trap theory to the U.S.-China relations.

\section{Alsu Tagirova}

Research Fellow, The Academy of History and Documentation of Socialism, East China Normal University, Shanghai, China aisu2007@hotmail.com 